\title{
The Morphological Processes Involved in the Lexicon of Iligan City's Tambal Binisaya
}

\author{
Lourd Greggory D. Crisol \\ Mindanao State University - Iligan Institute of Technology \\ crisol.lourdgreggory8@gmail.com
}

\section{Abstract}

Tambal Binisaya refers to the folk medicine used in Iligan City, Philippines. These medicines have been used for decades by mananambals or local folk healers and residents from low-income groups. However, because of modern treatments, the locals have started to move away from Tambal Binisaya. Because of this, many residents have become unfamiliar to Tambal Binisaya and the terms used in the trade. Thus, this ethnolinguistic study looked into the lexicon of Tambal Binisaya, specifically word formation processes involved in the names of these folk medicines. In doing so, the researcher employed interviews, observations and field notes in data gathering. Based on the results of the study, it was found that the morphological processes used are: affixation, enclitization, reduplication, metanalysis, compounding, blending, borrowing and coining. It is concluded that there indeed lies a rich trove of lexical items in Tambal Binisaya which should be given more societal and academic attention.

Keywords: alternative medicine, lexicon, morphology, folk customs, material culture

\subsection{Introduction}

Throughout classical antiquity, herbs, concoctions, wood extracts, and the like, have aided mankind for treatment of ailments and various maladies. The Mayans for instance, a tribe which lived in the lowlands of central America in 250 A.D. to 900 A.D., perceived health as "balance", whereas illness and disease were "imbalance". Mayan medical texts are devoted to the treatment of symptoms based upon the effects of certain herbal remedies which could be swallowed, smoked, snorted, rubbed on the skin, and even given as enemas (The British Association of Urological Surgeons, 2020).In the same manner, the nomadic tribe of the Aztecs which lived in Mexico from 1300 A.D. to their fall in the 1500s also used herbal medicine for treating sickness and diseases. These herbal medicines were documented by two Native American students at the College of Santa Cruz in Tlaltilulco, in 1552, during the early years of Spanish rule in Mexico. Today their work, Libellus de Medicinalibus Indorum Herbis which is Latin for "Little Book of the Medicinal Herbs of the Indians" is commonly called the Badianus Manuscript. Housed in the Vatican Library, The Badianus Manuscript is the oldest known American herbal manuscript. These herbal medicines are said to cure various illnesses such as nosebleeds, injuries, lightning 
stroke, cough, rumbling of the abdomen, "black blood", and heart pain (Emmart, 1940). This goes to show that herbal medicines are indeed intertwined with mankind's history.

More so, the age-old wisdom of the people of every country has been crystalized into different systems of traditional medicine, each nation having its own system. Some of these traditional systems are well established, supported by theories and rich experience and recorded in writing, such as the Indian system of Ayurveda, the Muslim system of Unani, traditional Chinese medicine, ancient Greek medicine and the systems that evolved from it, and the humoral theory and therapy of Latin America. Whether sophisticated or not, the systems of traditional medicine served as the only means of health care for ages till modern biomedicine came into being. In contrast to modern biomedicine, which was founded on the basis of modern natural sciences, most traditional systems of medicine originated in and developed according to the principles of ancient schools of philosophy (Xie, 2001).

Meanwhile, in the Philippines, the practice of folk medicine is thought to have existed for hundreds of years, even before the colonization by the Spaniards. The roots of traditional medicine appear to have originated from the practices of ethnic and indigenous groups of Filipinos. The assumption is that the spectrum of traditional medicine in the Philippines has been brought about by the influences mainly of ethnic Chinese traditional medicine systems, local folklore, and experiments with the use of medicinal resources from plant roots, to natural oils (Bodeker et al, 2005).

However, the Philippines, with the advent of being colonized by Spain for over 300 years, merged its ancestral beliefs with the formal Christian influence. The use of amulets to ward off sickness and to be protected from natural disasters and even from man-made aggression was now combined with prayers adapted from churches (Bodeker et al, 2005). In Iligan City, in particular, which is a predominantly Catholic city situated in northern Mindanao, these folk medicines are called as Tambal Binisaya which translates to 'binisaya medicine'. These medicines, which range from roots, stones, tree barks, seeds, oils, and amulets are sold by small-scale vendors near the St. Michael's Cathedral Parish and are said to treat various ailments and afflictions such as flatulence, dysmenorrhea, fever, flu, and constipation, to name a few. Some even claim to have medallions and charms to ward off curses, protect wearers from harm, and bless bearers with good luck in wealth and love. Among their usual customers are albularyos or folk healers and people coming from the low income groups.

Nevertheless, due to the prospering use of modern scientific treatments, people from the localities have started to move away from folk medicine, which in turn has led to the waning patronage to these traditional medicines. Hence, these kinds of folk treatments are placed on the fringes of Philippine society and culture. As supported by Berdon, Ragosta, Inocian, Manalag, \& Lozano (2016), the belief in folk medicine and its practice is already slowly diminishing as time passes by. Because of new inventions in medicine brought about by modernity, many people rely more on professional medical practitioners who use science or modern medicine to cure diseases. This entails that many people from the localities have become alienated to these folk medicinesto the point of not knowing their names or even 
how these medicines obtained their names. In fact, even in the academic community, there is a dearth of nomenclature studies on folk medicines.

This ethnolinguistic research was thus crafted to revive the awareness of mainstream society about Tambal Binisaya by studying the nomenclature of these folk medicines. Specifically, it will venture into morphological analysis to look into how the names of these folk medicines were coined. This kind of analysis is done by looking into the different ways of how words are shaped to express conceptual categories (Payne, 2006). Thus, morphological analysis deals with how words are formed.

\subsection{Methodology}

This research is qualitative in nature. It made use of an ethnolinguistic design on seven (7) selected Tambal Binisaya vendors in Iligan City, Philippines. These seven (7) selected Tambal Binisaya vendors served as the key informants and were chosen using purposive sampling.

Furthermore, an interview was used as the main research tool in the study. For the said interview, sets of guide questions were prepared by the researcher. In carrying out these questions, the local language, which is Cebuano-Visayan, was used. In the entire duration of the interview, the interviewer made use of a tape recorder and wrote field notes. These methods were utilized to determine the lexical items used in Tambal Binisaya. After data collection, the terms were then glossed with the aid of a Cebuano Visayan Dictionary for Cebuano-Visayan terms and scientific names (Wolff, 1972), Lexico, a website powered by Oxford University Press, for English loanwords, Tambal
Binisaya and proper names (Oxford dictionary, n.d.), and The New Philippines Comprehensive Dictionary \& Thesaurus for Filipino loanwords (Ignacio, 2009). After which, these lexical items were analyzed in terms of their morphological features. In doing so, the researcher was able to identify how these words were formed.

\subsection{Results and Discussion}

\subsection{Lexical items with Cebuano Roots}

Among the pool of lexical items used in, there are those which do not undergo modification (for a lack of a better term, modification will be used to refer to morphological processes). These unmodified lexical items all have CebuanoVisayan roots which express the basic meaning of a word and cannot be further divided into smaller morphemes (Payne, 2006). These unmodified words are shown in Table 1.

After careful analysis of the pool of lexical items, it was revealed that there are 11 unmodified Tambal Binisaya terms which all come from Cebuano-Visayan. These identified terms are found to have natural and supernatural associations. They are used for healing, protecting, and bringing good fortune. In terms of health/ medical implications, these medicines might seem ineffective to nonusers but this is by no means unusual because traditional plant remedies may be effective within the framework of a society's own understanding (Brown, 2003). That is, because of the Filipino's deep-rooted belief in the spiritual realm, these medicines then gain their efficacy. Moreover, the high number of unmodified Cebuano-Visayan terms is no surprise since Tambal Binisaya after all originated from Cebuano-Visayan speaking people. 
Table 1. Unmodified Tambal Binisaya Lexical Items

\begin{tabular}{|c|c|}
\hline Language Source & Meaning \\
\hline Ceb. bahay [bahal] & 'the tuberous roots of which are eaten in times of famine' \\
\hline $\begin{array}{l}\text { Ceb.balugbug } \\
\text { [balugbug] }\end{array}$ & $\begin{array}{l}\text { 'small tree bearing pods with three to six marble-sized and shaped } \\
\text { seeds'; 'it is used for protection from curses' }\end{array}$ \\
\hline Ceb. banag [banag] & $\begin{array}{l}\text { 'woody, spiked vine found in thickets, the tips and fruit of which are } \\
\text { used medicinally:Smilaxbracteata'; 'It is brewed and the extract is } \\
\text { drank. It is used for stomach problems" }\end{array}$ \\
\hline Ceb. dawa [dawa?] & 'millet: Setarialvaryi';'It is mixed in a habak' \\
\hline Ceb. habak [habak] & $\begin{array}{l}\text { 'a charm used for various purposes such as for protection, for } \\
\text { attracting good luck, for maintaining good health, etc.' }\end{array}$ \\
\hline $\begin{array}{l}\text { Ceb. kamangyan } \\
\text { [kamanjan] }\end{array}$ & $\begin{array}{l}\text { 'a dried form of the resin obtained from almasiga and other forest } \\
\text { trees. It is burned over coals for its smoke, which is used in folk } \\
\text { medicine and other rituals for magical purposes and also used as a } \\
\text { mosquito smudge or for other non-magical purposes' }\end{array}$ \\
\hline Ceb. lana [lana] & $\begin{array}{l}\text { 'a concoction of oil and herbs having special curative properties or } \\
\text { power to ward off evil of supernatural origin' }\end{array}$ \\
\hline $\begin{array}{l}\text { Ceb. sibukaw } \\
\text { [sibukaU] }\end{array}$ & $\begin{array}{l}\text { 'small tree with scattered prickles, the wood of which is used for nails } \\
\text { in boat building: Caesalpiniasappan';'It is brewed and the extract is } \\
\text { drunk.' }\end{array}$ \\
\hline $\begin{array}{l}\text { Ceb. tambagisa } \\
\text { [tambagisa] }\end{array}$ & $\begin{array}{l}\text { 'a kind of shrub of waste places, the leaves of which are used as a } \\
\text { poultice: Cassia sp.' }\end{array}$ \\
\hline Ceb. tawas [tawas] & $\begin{array}{l}\text { 'Alum'; 'Used by albularyos for treating their patients'; 'used as a } \\
\text { deodorant' }\end{array}$ \\
\hline Ceb. wagas [wagas] & 'pure gold, not worked into jewelry'; 'It is mixed in a habak as a charm' \\
\hline
\end{tabular}

\subsection{Morphological Processes}

A morphological process is a way of expressing a conceptual category by altering the shape of a word (Payne, 2006). Furthermore, morphological analysis is done since words can be chopped into smaller pieces. At the phonological level, words can be divided into syllables or segments, and segments into their constituent phonological features. At the morphological level, words may consist of more than one unit as well, which may be called as the morphological atoms of a word: pieces that are no further divisible into morphological subparts. Just as there are different kinds of atoms in chemistry, there are different kinds of atoms in morphology, and it is quite useful for morphological analysis to be acquainted with their classification. A good classification is an important analytic instrument, developed in order to get a better understanding of the structure and formation of words (Booij, 2005). In this case, the morphological analysis will give illumination on the nomenclature of the Tambal Binisaya terms. 
Some of these morphological processes are used in the terminologies of Tambal Binisaya and will be discussed in this section.

\subsubsection{Affixation}

An affix is a grammatical element which cannot form a word by itself. Affixes are bound morphemes, in the sense that they are meaningful units (morphemes) which cannot exist independently of another morpheme to which they must be attached. Most (but not all) of the world's languages contain grammatical affixes used for various purposes (Trask, 2007). In the terms used in Tambal Binisaya there are three affixes identified. These are: prefix, suffix and infix. It was found that these affixes could appear individually or with other affixes. This section discusses the affixations used in Tambal Binisaya.

\subsubsection{Prefix}

Affixes that are added to the beginning of the word (e.g. un-, mis-) are called prefixes (Yule, 2010). In the case of the Tambal Binisaya terms, there are some commonly used prefixes. These are presented in Table 2 .

As shown in Table 2, there are four lexical items which use prefixes. These terms could be categorized as instruments. The affixes maka(makabuhay), pang-(pangamay), tali- (talimughat), and pa- (paduguk), are all attached to terms which are used as charms and treatment or cure for ailments and sickness. This only goes to show that there is indeed a strong association between the prefixes and root words used in the Tambal Binisaya to afflictions and healing since these lexical items are all connected to actions (i.e. doing or causing something to be cured or be lucky, etc.).

Table 2. Prefixed Terms in Tambal Binisaya

\begin{tabular}{|c|c|c|c|c|c|}
\hline Prefix & Function & +Root word/s & Meaning & $\begin{array}{c}\text { Tambal } \\
\text { binisaya } \\
\text { term }\end{array}$ & Meaning \\
\hline maka- & $\begin{array}{l}\text { Potential active verb } \\
\text { affix which } \\
\text { refers to an action } \\
\text { something has the } \\
\text { capability of doing }\end{array}$ & Fil. buhay & Life & makabuhay & $\begin{array}{l}\text { Literally means to } \\
\text { give life. For the } \\
\text { tambal binisaya, } \\
\text { these are herbs used } \\
\text { to treat stomach } \\
\text { ulcer. }\end{array}$ \\
\hline Pang- & $\begin{array}{c}\text { Noun forming } \\
\text { affix. Specifically, } \\
\text { an instrument for [do] } \\
\text { ing }\end{array}$ & Fil. Kamay & 'hand' & pangamay & $\begin{array}{l}\text { 'It comes from the } \\
\text { balete tree and is } \\
\text { placed inside the } \\
\text { cashbox or mixed } \\
\text { inside a habak to } \\
\text { attract good fortune. } \\
\text { It is shaped like a } \\
\text { hand (Fil.kamay) } \\
\text { which is why it is } \\
\text { called pangamay.' }\end{array}$ \\
\hline
\end{tabular}


Table 2. Prefixed Terms in Tambal Binisaya (continued...)

\begin{tabular}{|c|c|c|c|c|c|}
\hline Prefix & Function & +Root word/s & Meaning & $\begin{array}{c}\text { Tambal } \\
\text { binisaya } \\
\text { term }\end{array}$ & Meaning \\
\hline tali- & $\begin{array}{l}\text { to a verb forming } \\
\text { adjectives meaning } \\
\text { 'about to [do] }\end{array}$ & Ceb. Bughat & $\begin{array}{l}\text { 'Sickness which } \\
\text { results from } \\
\text { leaving a sickbed } \\
\text { or rising from } \\
\text { childbirth too } \\
\text { early, or from } \\
\text { the return of a } \\
\text { disease' }\end{array}$ & 然 & $\begin{array}{l}\text { 'Bark of a tree used as } \\
\text { treatment for relapse } \\
\text { or bughat'. It is boiled } \\
\text { with water or wine } \\
\text { and the extract is } \\
\text { drank until the sick- } \\
\text { ness is cured. }\end{array}$ \\
\hline pa- & $\begin{array}{l}\text { derivational verb- } \\
\text { forming affix to which } \\
\text { inflectional affixes } \\
\text { are added without } \\
\text { morphopho-nemic } \\
\text { alternation. } \\
\text { referring to actions one } \\
\text { has caused some- } \\
\text { one to do (either to } \\
\text { something. else or to } \\
\text { oneself) } \\
\text { added to nouns: cause } \\
\text { someone to do [the ac- } \\
\text { tion that verbs derived } \\
\text { from the noun refer } \\
\text { to] }\end{array}$ & Ceb. duguk & $\begin{array}{l}\text { 'Go, to be } \\
\text { attracted to a } \\
\text { specific thing, } \\
\text { most often in } \\
\text { great numbers' }\end{array}$ & . & $\begin{array}{l}\text { 'A kind of incense } \\
\text { used to attract love, } \\
\text { money, or good } \\
\text { health depending on } \\
\text { the intention of the } \\
\text { person. It could also } \\
\text { be mixed in a habak.' }\end{array}$ \\
\hline
\end{tabular}

\subsubsection{Suffix}

Affixes that are added to the end of the word are called suffixes (Yule, 2010). In Tambal Binisaya, there are also some suffixes used. These are shown in the next table.

As shown in Table 3, there is only one suffix identified in the lexicon of Tambal Binisaya which is -an. Generally, the terms in this table got their names since they show qualities which resemble other objects. For example, the word duguan got its name because of the red extract which resembles blood (dugu).On the other hand, the word kapinan, which is derived from the word kapin (or excessive), got its name because of its elongated shape which is quite different from other usually rounded shells. Thus, it is called this way since it looks excessive compared to other shells. 
Table 3. Suffixed Terms in Tambal Binisaya

\begin{tabular}{|c|c|c|c|c|c|}
\hline Suffix & Function & Word & Meaning & $\begin{array}{c}\text { Tambal } \\
\text { binisaya term }\end{array}$ & Meaning \\
\hline \multirow[t]{3}{*}{-an } & \multirow{3}{*}{$\begin{array}{c}\text { adjective } \\
\text { forming } \\
\text { affix. forming } \\
\text { adjectives } \\
\text { which mean } \\
\text { 'characterized } \\
\text { by being [so- } \\
\text { and-so] }\end{array}$} & Ceb. dugu & ‘blood' & duguan & $\begin{array}{l}\text { 'twigs which are used to treat anemia } \\
\text { and for recovery during miscarriage. It is } \\
\text { boiled and the extract is drunk. It is called } \\
\text { this way because the extract is red which } \\
\text { resembles blood (dugu)'. }\end{array}$ \\
\hline & & Ceb. kapin & $\begin{array}{l}\text { 'be in } \\
\text { excess or } \\
\text { extra' }\end{array}$ & kapinan & $\begin{array}{l}\text { 'the donkey's ears abalone, or any oval- } \\
\text { shaped abalone, so called because there } \\
\text { is more flesh in proportion to the shell- } \\
\text { size than other types of bivalves' }\end{array}$ \\
\hline & & & & & $\begin{array}{l}\text { It has a shiny interior and is used as a } \\
\text { charm to be placed inside a habak or a } \\
\text { cash box. It brings fortune to the owner. }\end{array}$ \\
\hline
\end{tabular}

\subsubsection{Infix}

Affixes that are inserted into the middle of the verbal root are called infixes (Trask, 2007).Some samples used in Tambal Binisaya are shown in the next table.

As shown in Table 4, both these folk medicines are associated with treating ailments and they were named in such ways because they possess certain qualities which are analogous to other objects. For example, kinilkig is a kind of herb which appears like wood scrapings. In the same way, tinabu is named as such because this medicine is bound by twines.

Table 4. Inffixed Terms in Tambal Binisaya

\begin{tabular}{|c|c|c|c|c|c|}
\hline Infix & Function & Word & Meaning & $\begin{array}{c}\text { Tambal } \\
\text { binisaya term }\end{array}$ & Meaning \\
\hline \multirow[t]{2}{*}{-in- } & $\begin{array}{l}\text { Causative, } \\
\text { it is used to } \\
\text { associate }\end{array}$ & Ceb. tabu & $\begin{array}{l}\text { 'for two ends } \\
\text { to meet, make } \\
\text { them meet' }\end{array}$ & tinabu & $\begin{array}{l}\text { 'It is an herb used as an incense. It is } \\
\text { used as treatment for children who } \\
\text { cannot go to sleep.' }\end{array}$ \\
\hline & $\begin{array}{l}\text { with another } \\
\text { because } \\
\text { of similar } \\
\text { qualities. }\end{array}$ & Ceb. kilkig & 'scrapings' & kinilkig & $\begin{array}{l}\text { 'wood scrapings which are used for } \\
\text { the treatment of colic or heartburn'It } \\
\text { is boiled and the extract is drunk by } \\
\text { the patient. }\end{array}$ \\
\hline
\end{tabular}




\subsubsection{Enclitization}

Bound words and phrasal affixes are examples of clitics and the word that a clitic 'leans' on is its host. Clitics such as -'s and -'ve appear to the right of their hosts, like suffixes. Such clitics are called enclitics (Radford, Atkinson, Britain, Clahsen \& Spencer, 2009). In the case of Tambal Binisaya the only case of enclitization occurs because of language borrowing. This is the process involved in the term bardsnis (bird's nest), a charm used to draw in luck and good fortune to the user. Although there is a Cebuano-Visayan translation for this term which is salag sa langgam, the term bird's nest is retained. This is because of the prestige of English in the Philippine context. This is also because loanwords are normally adapted to the phonological (and phonetic) patterns of the language they are borrowed into, although if the source (or loaning) language is well known to most speakers of the borrowing language, this adaptation does not always occur (McGregor, 2009).

\subsubsection{Reduplication}

Reduplication is the process of repeating all or part of a form/word (Yule, 2010). The instance of the reduplicated word in Tambal Binisaya is shown in the next table.

As shown in Table 5, there is only one term which uses reduplication and that is kugangkugang. This word uses full reduplication and the morphological process has a two-fold function: one is to show resemblance. Since this herb is usually found in waste places, it shows a feature which makes it resemble kugang in CebuanoVisayan or scab in English. Thus, the name kugangkugang. The other one is to show the effect of the medicine which is to make the skin eruptions dry and become a kugang or scab.

Table 5. Reduplicated Tambal Binisaya Terms

\begin{tabular}{cccc}
\hline First word & Meaning & Reduplicated word & Meaning \\
\hline Ceb. Kugang & $\begin{array}{c}\text { 'dry crust, scab of a } \\
\text { sore or wound' }\end{array}$ & kugang-kugang & $\begin{array}{c}\text { 'low-growing, woody herb of waste places used } \\
\text { to treat children who have the skin eruptions' }\end{array}$ \\
\hline
\end{tabular}

\subsubsection{Metanalysis}

Metanalysis is from Greek meta 'change' + analysis 'analysis', and as the name suggests, metanalysis involves a change in the structural analysis, in the interpretation of which phonological material goes with which morpheme in a word or construction (Campbell, 1998). The history of English provides some nice examples of reanalysis involving nothing more than the movement of a morpheme boundary. One good example is the use of the English article $a(n)$. Forms like a napron and an ewt were apparently misheard as an apron and $a$ newt, producing the modern forms (Millar
\& Trasks, 2015). In Tambal Binisaya there are some examples identified which exhibit metanalysis.

It is shown in Table 6 that most of the metanalyzed terms in Tambal Binisaya are because of the presence of the ligative words in CebuanoVisayan. These ligative words are used to link one part of a sentence to another. Some examples are na which are created from the merging of two or more letters from which a single independent form is derived (Bussmann, 2006). Furthermore, the lexical items shown in the table are folk medicines which are used for treating pains and inflammation. 
Table 6. Metanalyzed Tambal Binisaya Terms

\begin{tabular}{|c|c|c|c|c|c|c|c|c|}
\hline $\begin{array}{l}\text { First } \\
\text { word }\end{array}$ & Meaning & $\begin{array}{l}\text { Second } \\
\text { word }\end{array}$ & meaning & $\begin{array}{l}\text { Third } \\
\text { word }\end{array}$ & meaning & $\begin{array}{c}\text { Tambal } \\
\text { binisaya } \\
\text { term }\end{array}$ & meaning & Etymology \\
\hline $\begin{array}{l}\text { Eng. } \\
\text { Ovary }\end{array}$ & $\begin{array}{l}\text { A female } \\
\text { reproductive } \\
\text { organ in } \\
\text { which ova } \\
\text { or eggs are } \\
\text { produced. }\end{array}$ & Ceb. na & 'which is' & & & Ubarina & $\begin{array}{l}\text { 'used as } \\
\text { treatment } \\
\text { for ovarian } \\
\text { problems } \\
\text { and } \\
\text { pregnancy. }\end{array}$ & $\begin{array}{c}\text { it is a cure for } \\
\text { "ubari na ga } \\
\text { hubag" (as shown } \\
\text { in the packaging) }\end{array}$ \\
\hline
\end{tabular}

\begin{tabular}{ccccc} 
Ceb. 'treat an & Ceb. 'stomach' Ceb. na 'which is' & Bugayana & 'Powdered 'The process of \\
Buga & illness by \\
expect- & tiyan & & mixture of using this product \\
rating & & herbs and is "ibuga sa tiyan \\
chewed & seed which & na gasakit" \\
medicinal & are used \\
herbs on a & to treat \\
sore spot & flatulence \\
or at the & and fever. \\
person's & It is boiled \\
stomach' & and the \\
& extract is \\
& drank.' \\
\hline
\end{tabular}

\subsubsection{Compounding}

Two separate words are sometimes joined together to form a single word, a new word with a new meaning of its own, a meaning that is not entirely predictable from the component words (McGregor, 2009). This morphological process is exhibited in the terms of Tambal Binisaya.

It is shown in Table 7 that there are six terms which use compounding. It can be observed that these terms are a combination of local words, loan words, and scientific names. Specifically, these terms have associations with charms and medication. The terms with English origins (seahorse, and horsetail), as well as scientific origin were retained from their origin language, and not translated to the local language because as mentioned earlier, there is prestige (and deemed potency) when using such words. On the other hand, the use of Cebuano-Visayan for the three other terms is quite straightforward. For example, batubalisa literally means 'purple stone' which is a literal description of the features of this purple incense. This kind of naming practice of the other Cebuano-Visayan derived terms follows the same principle. 
Table 7. Compounded Terms in Tambal Binisaya

\begin{tabular}{|c|c|c|c|c|c|}
\hline $\begin{array}{l}\text { First } \\
\text { word }\end{array}$ & Meaning & $\begin{array}{l}\text { Second } \\
\text { word }\end{array}$ & Meaning & $\begin{array}{c}\text { Compounded } \\
\text { term }\end{array}$ & Meaning \\
\hline $\begin{array}{l}\text { Ceb. } \\
\text { tawas }\end{array}$ & 'alum' & Ceb.tapul & $\begin{array}{l}\text { 'any variety of root crop, } \\
\text { grain, or beans that is } \\
\text { dark violet in color' }\end{array}$ & Tawastapul & $\begin{array}{l}\text { 'a kind of incense } \\
\text { which has a purple } \\
\text { shade'. It is used to } \\
\text { ward off evil spirits. }\end{array}$ \\
\hline $\begin{array}{l}\text { Ceb. } \\
\text { tagu }\end{array}$ & 'hide' & Ceb. laway & 'saliva' & Tagulaway & $\begin{array}{l}\text { 'a kind of talimughat } \\
\text { used as treatment for } \\
\text { relapse or bughat' }\end{array}$ \\
\hline $\begin{array}{l}\text { Ceb. } \\
\text { batu }\end{array}$ & $\begin{array}{l}\text { 'rock, stone, } \\
\text { pebble' }\end{array}$ & Ceb. balisa & $\begin{array}{l}\text { 'be anxious, } \\
\text { apprehensive' }\end{array}$ & Batubalisa & $\begin{array}{l}\text { 'seeds used to treat } \\
\text { affliction related to } \\
\text { curse }(d a-u t)^{\prime}\end{array}$ \\
\hline $\begin{array}{l}\text { Ceb. } \\
\text { agusu }\end{array}$ & 'Australian pine' & $\begin{array}{c}\text { Proper } \\
\text { Name: } \\
\text { kaswarina }\end{array}$ & $\begin{array}{l}\text { The scientific name } \\
\text { of aguhu: Casuarina } \\
\text { equistifolia. } \\
\text { Lumber and ornamental } \\
\text { tree. The roots and bark } \\
\text { have medicinal uses. }\end{array}$ & AgusuKaswarina & $\begin{array}{l}\text { dried shrubs } \\
\text { which are used to } \\
\text { treat relapse and } \\
\text { dysmenorrhea. It is } \\
\text { soaked in wine and } \\
\text { the extract is drank. }\end{array}$ \\
\hline $\begin{array}{l}\text { Eng. } \\
\text { horse }\end{array}$ & $\begin{array}{l}\text { A solid-hoofed } \\
\text { plant-eating } \\
\text { domesticated } \\
\text { mammal with a } \\
\text { flowing mane and } \\
\text { tail, used for } \\
\text { riding, racing, } \\
\text { and to carry and } \\
\text { pull loads. } \\
\text { (Oxford } \\
\text { dictionary, n.d.). }\end{array}$ & Eng. Tail & $\begin{array}{l}\text { The hindmost part of an } \\
\text { animal, especially when } \\
\text { prolonged beyond the } \\
\text { rest of the body, such as } \\
\text { the flexible extension of } \\
\text { the backbone in a } \\
\text { vertebrate, } \\
\text { the feathers at } \\
\text { the hind end } \\
\text { of a bird, or } \\
\text { a terminal appendage in } \\
\text { an insect (Oxford } \\
\text { dictionary, n.d.). }\end{array}$ & $\begin{array}{c}\text { Horsetail = } \\
\text { Hurstil }\end{array}$ & $\begin{array}{l}\text { herbs used to treat } \\
\text { stomach ulcers and } \\
\text { kidney stones. It is } \\
\text { said that it could } \\
\text { also boost appetite. } \\
\text { It is called horsetail } \\
\text { because it resembles } \\
\text { a horse's tail }\end{array}$ \\
\hline Eng. Sea & $\begin{array}{l}\text { The expanse of } \\
\text { salt water that } \\
\text { covers most of } \\
\text { the earth's surface } \\
\text { and surrounds } \\
\text { its landmasses } \\
\text { (Oxford } \\
\text { dictionary, n.d.). }\end{array}$ & Eng. horse & $\begin{array}{l}\text { A solid-hoofed plant- } \\
\text { eating domesticated } \\
\text { mammal with a } \\
\text { flowing mane and tail, } \\
\text { used for riding, racing, } \\
\text { and to carry and } \\
\text { pull loads (Oxford } \\
\text { dictionary, n.d.). }\end{array}$ & $\begin{array}{c}\text { Seahorse }= \\
\text { sihurs }\end{array}$ & $\begin{array}{l}\text { A water animal that } \\
\text { resembles a horse. In } \\
\text { the tambal binisaya, } \\
\text { this creature is dried } \\
\text { and used as a good } \\
\text { luck charm. It is } \\
\text { usually placed inside } \\
\text { a cash box. }\end{array}$ \\
\hline
\end{tabular}




\subsubsection{Blending}

Blends involve the combination of parts of two separate words to form a single word. Usually it is the first part (often syllable) of one word together with the second part of the other word (either syllable or single final consonant), which occur in that sequence (e.g. spork, smog, motel, etc.) (McGregor, 2009). The blended words in the Tambal Binisaya are shown in Table 8.

It is shown that the blended Tambal Binisaya terms are not just a combination of two (2) words but rather they combine up to three (3). Moreover, the word origins of these blended terms in Tambal Binisaya could be traced from three sources: one is from Cebuano-Visayan, another is from Filipino and lastly, the other is from a proper name. Moreover, it is revealed that all objects mentioned in the table are used as treatments for various ailments and sicknesses which have natural causations (i.e. they are not supernatural in nature).

Table 8. Blended Tambal Binisaya Terms

\begin{tabular}{|c|c|c|c|c|c|c|c|}
\hline $\begin{array}{l}\text { First } \\
\text { word }\end{array}$ & Meaning & $\begin{array}{l}\text { Second } \\
\text { word }\end{array}$ & Meaning & $\begin{array}{l}\text { Third } \\
\text { word }\end{array}$ & Meaning & Blended word & Meaning \\
\hline $\begin{array}{l}\text { Proper } \\
\text { Name: } \\
\text { China }\end{array}$ & $\begin{array}{l}\text { A country in } \\
\text { eastern Asia, } \\
\text { the third } \\
\text { largest and } \\
\text { most populous } \\
\text { in the world } \\
\text { (Oxford } \\
\text { dictionary, } \\
\text { n.d.). }\end{array}$ & $\begin{array}{l}\text { Fil. } \\
\text { gamot }\end{array}$ & 'medicine' & & & Chinamut & $\begin{array}{c}\text { used as } \\
\text { treatment } \\
\text { for relapse or } \\
\text { bughat. }\end{array}$ \\
\hline Ceb. buga & $\begin{array}{c}\text { 'treat an } \\
\text { illness by } \\
\text { expectorating } \\
\text { chewed } \\
\text { medicinal } \\
\text { herbs on a } \\
\text { sore spot or at } \\
\text { the person' }\end{array}$ & $\begin{array}{l}\text { Ceb. } \\
\text { tiyan }\end{array}$ & 'stomach' & Ceb. na & $\begin{array}{l}\text { 'metanalyzed } \\
\text { From the } \\
\text { phrase } \\
\text { "nasakit"' }\end{array}$ & Bugayana & $\begin{array}{c}\text { Powdered } \\
\text { mixture of } \\
\text { herbs and } \\
\text { seed which are } \\
\text { used to treat } \\
\text { flatulence and } \\
\text { fever. }\end{array}$ \\
\hline $\begin{array}{l}\text { Ceb. } \\
\text { dugus }\end{array}$ & 'honey' & Ceb.na & $\begin{array}{l}\text { 'Which is } \\
\text { used for' }\end{array}$ & $\begin{array}{l}\text { Fil. } \\
\text { gamot }\end{array}$ & 'medicine' & dugusaynamut & $\begin{array}{c}\text { used as } \\
\text { treatment } \\
\text { for relapse or } \\
\text { bughat. }\end{array}$ \\
\hline
\end{tabular}

\subsubsection{Borrowing}

Borrowing is the process of incorporating into one language words from another. It is perhaps the most common source of new words. Words that have been borrowed are called loanwords. Loanwords are normally adapted to the phonological (and phonetic) patterns of the language they are borrowed into, although if the source (or loaning) language is well known to most speakers of the borrowing language, this 
adaptation does not always occur (McGregor, 2009). In the lexicon of Tambal Binisaya there are many words which have been borrowed from other languages such as Filipino, Spanish and English. They have even made modification to these loanwords words to make them more CebuanoVisayan sounding. Table 9 shows the loanwords in Tambal Binisaya and their origins.

It is shown that the highest frequency of borrowed words in Tambal Binisaya come from Spanish. This is no wonder because the Spaniards colonized the Philippines for more than 300 years which is why many Spanish words made their way into the Cebuano-Visayan language. The Second highest frequency of loanwords comes from English. In accounting for these loan words, there are two possible reasons which could be surmised. First is that, English holds social prestige in Philippine society (Bautista, 1996). Thus if a product is in English then the customers, given their socio-economic background, would perceive them as effective or more potent. Moreover, the second reason which could account for borrowing in English is the lack of such words. This information was obtained when the researcher asked one of the vendors "Is there a Cebuano word for seahorse?" and the vendor replied "It is really like that. Why? Do you know any Cebuano words for that?"
Among the borrowed words, least come from Filipino and Proper names. The reason for this is that the product Chinamot and Dugusaynamut already have packaging and were only ferried from Cebu City, Philippines to Iligan City, Philippines. In fact, these products are distributed in many parts of the country. On the other hand, pangamay most likely is called this way because it would not be semantically sound if the Cebuano-Visayan word kamot would be used. As such there is already a meaning attached to pangamot which is 'to do something by one's own hand' (Wolff, 1972). That is why pangamay is preferred over pangamot to refer to the good luck charm. In the case of makabuhay, the borrowing of such word has a similar reason with the borrowing of English words since Tagalog treatments are deemed by many people in the rural provinces in the Philippines to have a more potent effect. This is due to many Filipinos (usually from low-income groups) seeing Manila City, and Tagalog speakers as more progressive and having better statures in life. Thus, makabuhay is the term used over the word makabuhi. Finally, in the case of Agusu Kaswarina, this also has a similar effect with the use of English since there is prestige in the use of foreign sounding words. Thus, there might be a perceived potency in the product because of the use of such scientific word.

Table 9. Tambal Binisaya Loanwords

\begin{tabular}{cccc}
\hline English & Spanish & Filipino & Proper Names \\
\hline Bardsnis (Bird's nest) & Midalyun (Medallion) & Chinamut (China + gamot) & Chinamut (China + \\
Hurstil (Horsetail) & Brilyanti (Brillante) & Dugusaynamut & gamot) \\
milyundalar (Million Dollar) & Ilipanti (Elefante) & (dugus+gamut) & AgusuKaswarina \\
sihurs (Seahorse) & Pulsiras (Pulsera) & Pangamay (kamay) & (The scientific name \\
ubarina (Ovary) & Asupri (Azufre) & Makabuhay (buhay) & of aguhu: Casuarina \\
& Kandila (Candela) & & equistifolia.) \\
& Kulantru (Culantro) & & \\
& Insinso (Incienso) & & \\
\end{tabular}




\subsubsection{Coining}

This morphological process involves the invention of totally new terms (Yule, 2010). In the case of Tambal Binisaya, there is only one identified term which is coined and that is maragaya. It is a cruder version of bugayana since bugayana is already powdered and packaged. According to the vendors, this is the same as bugayana but it is not powdered. Also, they mentioned that bugayana already has other mixtures like kulantro. This is how the term maragaya was coined because of the attempt to imitate a more established medicine, bugayana.

\subsection{Unaccounted terms}

After careful analysis of the data, it was found that there are some Cebuano-Visayan terms which are not accounted for in Wolff's Cebuano Visayan Dictionary. One of these terms is inggu which is made of pili (Canarium ovatum) seeds. The seeds are mixed inside a bottle of habak or burned like an incense to protect pregnant women from supernatural harm. Another term not found in the Cebuano dictionary is asibar which is made of seeds from the mahogany tree. It is used to induce menstruation or could be used to treat abnormal menstrual cycle. However, if used wrongly, it could also cause miscarriage. As revealed in the accounts of the vendors, some women even buy the medicine to intentionally abort their babies.

Lastly, it is also important to note that according to the respondents these two words are indeed local and have been used by their katiguwangan or 'ancestors' long before.

\subsection{Conclusion and Recommendation}

There indeed lies a rich trove of terms or lexical items in the Tambal Binisaya trade which were created out of ingenuity and creativity of the speakers. In fact, there are even terms which were not accounted for in Wolff's Cebuano Visayan Dictionary. Unfortunately, many people, even those in the locality, are not aware anymore of these terms since many of them do not use these Tambal Binisaya medicines anymore.

Furthermore, these, should be given more societal and academic attention because these serve important functions in Philippine culture such as reinforcing the Filipino identity through an existing tangible heritage. And even though it is good to embrace the world and become global citizens, it should not be at the expense of a nation's own identity and heritage.

More so, this study reminds people of the importance of their health. It reminds them to revisit traditional practices for possible treatments to modern sicknesses and ailments. As mentioned by Maryland University of Integrative Health (2018), [the modern study of] herbal medicines draw from traditional systems of healing as well as contemporary evidenced based medicine to support and restore optimal health. This underscores the relationship of using traditional means with modern means to achieve maximum vitality. After all, health is everyone's concern.

Finally, it can be concluded that the rich pool of lexical items used in emerged because of the experiences encountered by the vendors, the makers, and the clients of these medicines. This is because all speech occurs in an interactive context in which interactants - speakers and hearers - make choices from the linguistic system. These include lexical and grammatical choices that express appropriate experiential meaning, that is, meaning concerned with the construal of the world of 
experience (McGregor, 2009). Thus, these lexical items, which are formed because of particular use of morphological processes, were shaped into what they are because of the need to satisfy the functional and contextual dimensions in this trade.

\section{References}

Bautista. M. L. (1996). Readings in Philippine sociolinguistics. Malate, Manila: De La Salle University Press, Inc.

Berdon, Z. J. S., Ragosta, E. L., Inocian, R. B., Manalag, C. A. \& Lozano, E. B. (2016). Unveiling Cebuano traditional healing practices. Asia Pacific Journal of Multidisciplinary Research, 4(1), 51-59.

Bodeker, G., Ong, C., Grundy, C., Burford, G.,\& Shein, K. (2005). WHO global atlas of traditional, complementary and alternative medicine. Kobe, Japan : WHO Centre for Health Development.

Booij, G. (2005). The grammar of words: An introduction to linguistic morphology. New York, USA.

The British Association of Urological Surgeons. (2020). Mayan medicine: Religion, ritual \& science. Retrieved from https://www.baus. org.uk/museum/88/mayan_medicine

Brown, M. F. (2003). Who owns native culture? London, England: Harvard University Press.

Bussmann, H. (2006). Routledge dictionary of language and linguistics. Abingdon, Oxon:
Routledge.

Campbell, L. (1998). Historical linguistics: An introduction. Cambridge Massachusetts: The MIT Press.

Emmart, E, W. (1940). Badianus manuscript: An Aztec herbal, 1552. Baltimore: Johns Hopkins Press. Retrieved from http://exhibits.hsl.virginia. edu/herbs/badianus/

Ignacio, M. L. (Ed.). (2009). The New Philippines comprehensive dictionary \& thesaurus : With Philippines (8) major languages. Philippines: Children's Press Publication \& Printing, Inc.

Maryland University of Integrative Health. (2018, October 10). Explore MUIH- herbal medicine [Video]. Retrieved from https://www. youtube.com/watch?v=mjxlkghbxNE

McGregor, W. B. (2009). Linguistics: An introduction. New York: Continuum International Publishing Group.

Millar, R. M., \& Trask, L. (2015). Trask's historical linguistics. Routledge.

Oxford dictionary (n.d.). China. In Oxford Dictionary. Retrieved June 20, 2020, from https://www. lexico.com/definition/china

Oxford dictionary (n.d.). Horse. In Oxford Dictionary. Retrieved June 20, 2020, from https://www. lexico.com/definition/horse

Oxford dictionary (n.d.). Sea. In Oxford Dictionary. Retrieved June 20, 2020, from https://www. 
lexico.com/definition/sea

Oxford dictionary (n.d.). Tail. In Oxford Dictionary. Retrieved June 20, 2020, from https://www. lexico.com/definition/tail

Payne, T. (2006). Exploring language structure: A student's guide. New York: Cambridge University Press.

Radford, A., Atkinson, M., Britain, D., Clahsen, H., \& Spencer, A. (2009). Linguistics: An introduction. Cambridge University Press.

Trask, R.L. (2007). Language and linguistics: The key concepts. Abingdon, Oxon: Routledge.

Wolff, J. (1972). A dictionary of Cebuano Visayan. New York City: Cornell University Press.

Xie, Z. F. (2001). Harmonization of traditional and modern medicine. In R. R. Chaudhury \& U. M. Rafei (Eds.), Traditional Medicine in Asia, (pp. 115-134). New Delhi: WHO Regional Office of Southeast Asia.

Yule, G. (2010). The study of language. New York, USA: Cambridge University Press. 